\title{
Nutritional evaluation of elephant-grass silages with byproduct of annato ${ }^{1}$
}

\section{Margareth Maria Teles Rêgo ${ }^{2}$, José Neuman Miranda Neiva ${ }^{3}$, Aníbal Coutinho do Rêgo ${ }^{4}$, Magno José Duarte Cândido ${ }^{5}$, Rossana Herculano Clementino ${ }^{6}$, João Restle ${ }^{7}$}

\footnotetext{
1 Pesquisa financiada pela CAPES-PROCAD, CNPq e FUNCAP

2 Universidade Federal do Rio Grande do Norte. Bolsista do CNPq.

${ }^{3}$ Universidade Federal do Tocantins. Bolsista do CNPq.

4 UNESP - Jaboticabal.

5 Universidade Federal do Ceará, bolsista do CNPq

6 Universidade Federal Rural de Pernambuco. Bolsista do CNPq

${ }^{7}$ Universidade Federal de Goiás. Bolsista do CNPq.
}

\begin{abstract}
The objective of the present study was to evaluate the nutritional value of elephant-grass silages containing annato byproduct. Twenty intact rams were distributed in a complete randomized block design with five diets $(0 ; 4 ; 8 ; 12$ and $16 \%$ annato byproduct in the silage) and four replications and used to estimate the intake, apparent nutrient digestibility, content of total digestible nutrients and nitrogen balance. The addition of annato byproduct raised the intakes of dry matter (DM), organic matter (OM), crude protein (CP), neutral detergent fiber (NDF), acid detergent fiber (ADF) ether extract (EE), total carbohydrates (TC), non-fibrous carbohydrates (NFC) and total digestible nutrients (TDN), in body weight (\%BW) and in metabolic weight (g kg-1BW0.75). The digestibilities of DM (55.95\%), OM (58.19\%), CP (45.34\%), NDF (52.79\%), ADF (45.79\%), EE (34.96\%) and NFC (99.86\%) were not influenced by the addition of annato byproduct. The inclusion of annato byproduct in elephant-grass silage increased digestibility of total carbohydrates, the TDN content and the nitrogen balance. The aditions of annato byproduct at levels up to $16 \%$ of the elephant grass silage natural matter improves nutrient intake and nitrogen balance.
\end{abstract}

Key Words: Bixa orellana, ensilage, nutritive value, pennisetum purpureum, tropical grass

\section{Avaliação nutricional de silagens de capim-elefante contendo subproduto do urucum}

\begin{abstract}
RESUMO - Objetivou-se avaliar o valor nutritivo de silagens de capim-elefante contendo subproduto do processamento do urucum. Vinte ovinos machos, não-castrados, foram distribuídos em delineamento inteiramente casualizado com cinco dietas $(0 ; 4 ; 8 ; 12$ e 16\% de subproduto de urucum na silagem) e quatro repetições, e utilizados para estimar o consumo, a digestibilidade aparente de nutrientes, o teor de nutrientes digestíveis totais e o balanço de nitrogênio. A adição de subproduto de urucum elevou os consumos de matéria seca (MS), matéria orgânica (MO), proteína bruta (PB), fibra em detergente neutro (FDN), fibra em detergente ácido (FDA), extrato etéreo (EE), carboidratos não-fibrosos (CNF), carboidratos totais e nutrientes digestíveis totais (NDT), tanto em relação ao peso vivo (\%PV) quanto em relação ao peso metabólico (g kg-1PV0,75) As digestibilidades de MS (55,95\%), MO (58,19\%), PB (45,34\%), FDN (52,79\%), FDA (45,79\%), EE (34,96\%) e CNF (99,86\%) não foram influenciadas pela adição de subproduto de urucum. A inclusão de subproduto de urucum na silagem de capim-elefante promoveu aumento na digestibilidade dos carboidratos totais, no teor de NDT e no balanço de nitrogênio A adição de subproduto de urucum em níveis de até $16 \%$ da matéria natural na ensilagem de capim-elefante melhora o consumo de nutrientes e o balanço de nitrogênio.
\end{abstract}

Palavras-chave: Bixa orellana, ensilagem, gramíneas tropicais, valor nutritivo

\section{Introduction}

Low availability of forage in the dry season of the year reduces the support capacity of the pasture, making it essential to establish a strategy for forage conservation and silage and hay are the forms most used (Vilela; Carneiro, 2002).
Among the tropical grasses, elephant grass (Pennisetum purpureum Schum.), much used in paddocks for cutting, is important as forage for silage because of its high production per area and good nutritional value. Although it presents high production and reasonable quality, according to several authors (Lavezzo, 1985; Nussio et al., 2002; Vilela; Carneiro; 2002) the excessive moisture in 
elephant grass at the ideal cutting time is the main limiting factor for silage, that according to Wilkinson (1983), favors low osmotic pressure, resulting in the development of bacteria of the Clostridium genus that contribute to significant losses in silage quality, reduced palatability and intake.

Several research studies have been developed testing absorbent additives to reduce the problem of high moisture in elephant grass at the time of ensilage. Several byproducts from agroindustry have been used as additives to elephant grass silage, such as orange pulp, which improved fermentation and raised the silage nutritive value (Faria et al., 1972); passion fruit byproduct that in addition to improving the fermentation process improved the intake and digestibility of the dry matter (DM), crude protein (CP) and neutral detergent fiber (NDF) (Reis et al., 2000); pineapple byproduct that improved DM intake (Ferreira et al., 2009) and coffee hulls that increased the DM contents but also increased the NDF, insoluble nitrogen in acid detergent (NIDA) contents in addition to reducing the DM digestibility (Bernardino et al., 2005).

With the installation of agroindustries in the Brazilian Northeast, several byproducts have become available and have been assessed for use as alternative foods in livestock raising in the region that might reduce animal production costs. Approximately 2,500 tons of annato (Bixa orellana L.) byproduct, after bixine (coloring) extraction, are obtained in Brazil (Souza; Faria, 2000), especially in the northeastern region where almost $97 \%$ of the residue is not used.

Gonçalves et al. (2006) assessed the effects of adding annato byproduct to elephant grass silage and observed improvement in the fermentation characteristics of the silage. In the study quoted, the byproduct presented $85.08 \%$ dry matter, 2.90 ether extract, $14.57 \%$ crude protein, 55.91\% neutral detergent fiber, $25.39 \%$ acid detergent fiber and $32.50 \%$ hemicellulose

Clementino (2008) assessed the nutritive value of annato byproduct and observed that sheep fed diets containing up to $80 \%$ of the referred byproduct increased linearly the intakes of dry matter, crude protein, fibrous fractions in addition to nonfibrous carbohydrates and total digestible nutrients. This author further observed that the apparent digestibilities of the dry matter, organic matter, crude protein and total carbohydrates and the nitrogen balance increased linearly with the inclusion of annato byproduct in substitution for Tifton 85 grass hay.

The objective of the present study was to assess the intake and digestibility of the nutrients of elephant grass silage with the addition of annato byproduct.

\section{Material and Methods}

The addition of five levels (1, 4, 8, 12 and 16\%, based on the natural matter) of dehydrated annato (Bixa orellana L.) byproduct in elephant grass (Pennisetum purpureum, Schum) ensilage was studied.

To make the experimental silage, elephant grass was used from a field already established on Fazenda Experimental Vale do Curu in Pentecoste, Ceará, Brazil, which belongs to Universidade Federal do Ceará (UFC). Prior to cutting, the area was mulched with $50 \mathrm{~kg} \mathrm{~N}$ and $40 \mathrm{~kg} \mathrm{~K}_{2} \mathrm{O}$ as urea and potassium chloride, respectively. The grass, at approximately 70 days of growth, was manually cut and processed in a conventional forage chopper, regulated to cut particles sized between 1 to $2 \mathrm{~cm}$. After chopping, the elephant grass was mixed with the byproduct derived from seed processing to extract the bixine.

The annato byproduct was obtained from Agroindústria Serra Grande after extracting bixine from annato seeds. The material obtained from the industry was ground in a hammertype grinder with a 0.2 -cm mesh sieve.

Plastic 210-L drums were used as experimental silos. After weighing and homogenizing, $126 \mathrm{~kg}$ of elephant grass plus annato byproduct were placed in the silos and compacted by stamping to reach $600 \mathrm{~kg} \mathrm{~m}^{-3}$ specific mass. After being filled, the silos were closed with plastic sheeting attached by rubber clips. The silos were opened 35 days after filling.

At ensilage, the elephant grass presented $22.01 \%$ dry matter (DM), 88.5\% organic matter (OM), 5.0\% crude protein (CP), $77.3 \%$ neutral detergent fiber (NDF), $48.1 \%$ acid detergent fiber (ADF), 29.2\% hemicellulose, 3.9\% ether extract (EE), 79.6\% total carbohydrates (TC), 2.3\% nonfibrous carbohydrates (CNF), 48.7\% insoluble nitrogen in neutral detergent (NIDN, \% of the total $\mathrm{N}$ ) and 16.2\% insoluble nitrogen in acid detergent (NIDA, \% of total $\mathrm{N}$ ). The annato byproduct presented in its composition 92.8\% dry matter, $92.9 \%$ organic matter, $16.6 \%$ crude protein, 42.4\% neutral detergent fiber, $22.3 \%$ acid detergent fiber, $20.2 \%$ hemicellulose, $7.2 \%$ ether extract, $69.2 \%$ total carbohydrates, $26.7 \%$ non-fibrous carbohydrates, 34.9\% insoluble nitrogen in neutral detergent ( $\%$ of total $\mathrm{N}$ ) and $12.2 \%$ insoluble nitrogen in acid detergent (\% total $\mathrm{N}$ ), based on the DM (Table 1).

To assess the intake and apparent digestibility of the silage and the nitrogen balance, 20 intact crossbred rams at average body weight of $18.8 \mathrm{~kg}$ were used, distributed in a complete randomized design with five levels of annato byproduct in the silage $(1,4,8,12$ and $16 \%)$ and four replications, considering the animals as experimental units. Silage from a single experimental silo was used for each 
group of animals. At the begining of the experiment, the animals were wormed, weighed and randomly distributed in the assessed treatments. They were weighed again at the end of the experimental period.

The sheep were housed in metabolism cages, with troughs to supply water, mineral mixture and experimental diet. The experiment lasted 17 days, in which 12 days were for adaptation of the animals to the diets and to the experimental environment and five days were for sample collection. The silage was supplied freely twice a day, in the morning and in the afternoon, and the quantity offered was daily calculated from the intake of the previous day, so that there were leftovers of approximately $15 \%$.

Feed consumption was determined by weighing the food offered and the leftovers during the data collection period. On this occasion, compound samples were taken from the foods, leftovers and feces that were kept at $-10^{\circ} \mathrm{C}$ for later analysis. Urine was measured in the morning, when a $10 \%$ aliquot of the total was collected, placed in flasks and kept at $-10^{\circ} \mathrm{C}$ for later analysis. To prevent nitrogen losses by volatilization, $20 \mathrm{ml}$ of chloric acid 1:1 were added to the urine collecting recipients. to prevent nitrogen losses by volatilization.

It was assed intakes, digestibility of the nutrients and the nitrogen balance of the silage and the content of total digestible nutrients, according to Sniffen et al. (1992). Contents of dry matter (DM), organic matter (OM), crude protein(CP), neutral detergent fiber (NDF), acid detergent fiber (ADF) and ether extract (EE) were determined according to methodology reported by Silva \& Queiroz (2002) and the values for total carbohydrates were obtained by the difference, according to methodology reported by Sniffen et al. (1992), where TC $(\%)=100-(\% \mathrm{CP}+\% \mathrm{EE}+\%$ ash $)$ and $\mathrm{TDN}(\%)=\mathrm{PBD} \%+\mathrm{FDND} \%+\mathrm{CNFD} \%+(2.25 \times \mathrm{EED} \%)$. The CNF contents were calculated from the difference between the total carbohydrates and NDF, according to Hall (2001).
The data obtained were first analyzed to meet the assumptions of normality, additivity and homoscedasticity. The values found for the CNF digestibility were transformed to $\log _{10}$ to proceed to the analysis of regression.

Analyses of variance and regression were carried out on the data for intake and digestibility of nutrients and nitrogen balance. Models were chosen based on the significance of the linear and quadratic coefficients, by the Student T-test, at the levels of 1 and 5\% probability. The PROC REG procedure of the SAS (2001) software was adopted as a tool for the statistical analyses.

\section{Results and Discussion}

The addition of annato byproduct to elephant grass silage increased the intakes of dry matter, crude protein, neutral detergent fiber, acid detergent fiber, ether extract, total carbohydrates, non-fibrous carbohydrates and total digestible nutrients, when expressed in percentage of body weight and in $\mathrm{g} \mathrm{kg}^{-1} \mathrm{BW}^{0.75}$ (Table 2). For each $1 \%$ of annato byproduct added, the dry matter intake was raised by $1.95 \mathrm{~g} \mathrm{~kg}^{-1} \mathrm{BW}^{0.75}$ while for the DM intake expressed in $\% \mathrm{BW}$, the addition of annato byproduct increased the DM by 0.093 percentage point at each $1 \%$ addition of annato byproduct.

This fact can be explained by the higher contents of dry matter in the silages containing the annato byproduct. According to Van Soest (1994), dry matter ingestion increased with the increase in the dry matter content of the foods. Neiva et al. (2006) worked with addition levels of 0. 3.5, 7.0. 10.5 and $14.0 \%$ dehydrated byproduct from passion fruit juice production into elephant grass ensilage and observed increase in the DM intakes of the silage. Acting similarly to dehydrated byproducts to raise the dry matter contents in silage, Ferreira et al. (2009) observed a linear increase in dry matter intake with the addition of $0 ; 3.5 ; 7.0 ; 10.5$ and $14.0 \%$ dehydrated pineapple byproduct.

Table 1 - Chemical composition of the elephant grass silage containing annato byproduct

\begin{tabular}{|c|c|c|c|c|c|}
\hline & \multicolumn{5}{|c|}{ Level of annato by-product in the silage (\%) } \\
\hline & 0 & 4 & 8 & 12 & 16 \\
\hline Dry matter $(\%)$ & 22.03 & 23.03 & 27.38 & 28.76 & 31,29 \\
\hline Neutral detergent fiber (\%) & 5.87 & 6.98 & 7.07 & 8.60 & 8,22 \\
\hline Acid detergent fiber (\%) & 73.68 & 70.84 & 69.75 & 66.78 & 67.00 \\
\hline Hemicellulose (\%) & 48.12 & 44.13 & 43.72 & 42.57 & 40.43 \\
\hline Dry matter $(\%)$ & 25.56 & 26.71 & 26.02 & 24.22 & 26.56 \\
\hline Total carbohydrates (\%) & 81.36 & 79.95 & 79.77 & 78.83 & 79.34 \\
\hline Nonfibrous carbohydrates (\%) & 7.69 & 9.11 & 10.03 & 12.04 & 12.33 \\
\hline Neutral detergent insoluble nitrogen ( $\%$ total $\mathrm{N}$ ) & 27.84 & 26.77 & 27.20 & 26.30 & 28.36 \\
\hline Acid detergent insoluble nitrogen (\% total $\mathrm{N}$ ) & 18.03 & 15.83 & 15.67 & 14.15 & 16.32 \\
\hline
\end{tabular}


Accordingly, this study confirmed the advantage of adding byproducts with high DM content in elephant grass ensilage as absorbent material, which resulted in an improvement in the silage fermentation process with adequate moisture levels, as reported in the studies by Evangelista et al. (2000), Gonçalves et al. (2006), Coan et al. (2007), Ribeiro et al. (2009) and Tavares et al. (2009).

In addition to the increase in the DM content in the silages, the increase in the crude protein content (Table 1) of $5.87 \%$ in the silage of elephant grass alone to $8.60 \%$ in the silage containing $12 \%$ annato byproduct, may have favored greater nitrogen input in the rumen environment and consequently greater digestibility and greater intake (36.67\% vs $48.40 \%$ and $3.20 \mathrm{gPB} / \mathrm{kgPV}^{0.75}$ vs $4.43 \mathrm{gPB} / \mathrm{kgPV}^{0.75}$, respectively).

It is further emphasized that all the silages assessed permitted DM intake greater than those established by the ARC (1980) of $42 \mathrm{~g} \mathrm{~kg}^{-1} \mathrm{BW}^{0.75}$ for sheep ingesting forage, and the NRC (2007) of $48 \mathrm{~g} \mathrm{~kg}^{-1} \mathrm{PV}^{0.75}$. According to Crampton et al. (1960) the ingestion of $80 \mathrm{~g} \mathrm{DM} \mathrm{kg}^{-1} \mathrm{BW}^{0.75}$ characterizes alfalfa hay as the standard for possible comparisons. Thus, the DM intake for the silage containing $16 \%$ annato byproduct approximated this value, with a mean of $76.4 \mathrm{~g} \mathrm{~kg}^{-1} \mathrm{BW}^{0.75}$.

For the organic matter intake expressed in \%BW, the increase was 0.09 percentage point $(\mathrm{P}<0.01)$ for each $1 \%$ annato byproduct included. For the intake expressed in $\mathrm{g} \mathrm{kg}^{-1} \mathrm{BW}^{0.75}$, at each $1 \%$ inclusion of annato byproduct, the organic matter intake increased by $1.87 \mathrm{~g} \mathrm{~kg}^{-1} \mathrm{BW}^{0.75}$.
The organic matter intakes suggested the same tendency observed for the dry matter intakes.

The crude protein intakes expressed in \%LW increased 0.011 percentage point $(\mathrm{P}<0.01)$ for each $1 \%$ of addition of annato byproduct at the elephant grass ensilage. For intake expressed in $\mathrm{g} \mathrm{kg}^{-1} \mathrm{PV}^{0.75}$ the $\mathrm{CP}$ intake increased $(\mathrm{P}<0.01)$ by $0.23 \mathrm{~g} \mathrm{~kg}^{-1} \mathrm{PV}^{0.75}$ for every $1 \%$ of annato product included. The increase in CP intakes was justified because adding the annato byproduct raised the DM contents in the silage permitting, according to Van Soest (1994), greater DM intakes. Together with this report, it can also be stated that the increase in the silage crude protein content (Table 1) favored better intake when annato byproduct was added to the silage.

It is emphasized that the CP intakes of the silage with the addition of annato byproduct were greater than those observed for silage considered a good quality one. Additions of over $4 \%$ of annato byproduct at elephant grass ensilage, $4.79 \mathrm{~g} \mathrm{~kg}^{-1} \mathrm{BW}^{0.75}$ were greater than the $\mathrm{CP}$ intakes observed by Neiva et al. (2006) who studied elephant grass silage containing byproducts from passion fruit processing and observed intakes of only $4.4 \mathrm{~g} \mathrm{~kg}^{-1} \mathrm{BW}^{0.75}$ with the addition of $10.5 \%$ of the referred byproduct. Neiva et al. (2006) classified the passion fruit processing byproduct as an effective absorbent and nutritive addition due to the nutritional improvement obtained.

Increase in the NDF intake of the silages expressed in \%BW was 0.05 percentage point for each $1 \%$ of annato byproduct included and when expressed in $\mathrm{g} \mathrm{kg}^{-1} \mathrm{BW}^{0.75}$,

Table 2 - Nutrient intake in sheep fed elephant grass silage containing annato byproduct

\begin{tabular}{|c|c|c|c|c|c|c|c|c|}
\hline & \multicolumn{5}{|c|}{ Level of annato by-product in the silage (\%) } & \multirow[t]{2}{*}{ Regression } & \multirow[t]{2}{*}{$\mathrm{R}^{2}$} & \multirow[t]{2}{*}{ CV (\%) } \\
\hline & 0 & 4 & 8 & 12 & 16 & & & \\
\hline \multicolumn{9}{|c|}{ Intake (\% LW) } \\
\hline Nutrient & 2.39 & 2.41 & 3.06 & 2.34 & 4.28 & $\hat{\mathrm{Y}}=2.16+0.093 \mathrm{X}^{* *}$ & 0.39 & 22.24 \\
\hline Dry matter (\%) & 2.11 & 2.14 & 2.75 & 2.13 & 3.89 & $\hat{\mathrm{Y}}=1.90+0.09 \mathrm{x}^{* *}$ & 0.42 & 22.28 \\
\hline Organic matter (\%) & 0.15 & 0.18 & 0.23 & 0.22 & 0.35 & $\hat{\mathrm{Y}}=0.14+0.011 \mathrm{x} * *$ & 0.66 & 20.07 \\
\hline Crude protein & 1.68 & 1.65 & 2.08 & 1.49 & 2.82 & $\hat{\mathrm{Y}}=1.52+0.05 \mathrm{x} * *$ & 0.28 & 23.95 \\
\hline Neutral detergent fiber & 1.05 & 1.00 & 1.27 & 0.94 & 1.66 & $\hat{\mathrm{Y}}=0.95+0.03 \mathrm{x}^{*}$ & 0.25 & 22.74 \\
\hline Acid detergent fiber & 0.05 & 0.06 & 0.09 & 0.06 & 0.12 & $\hat{\mathrm{Y}}=0.05+0.003 \mathrm{x} * *$ & 0.45 & 27.66 \\
\hline Ether extract & 1.91 & 1.90 & 2.43 & 1.85 & 3.41 & $\hat{\mathrm{Y}}=1.71+0.07 \mathrm{X}^{* *}$ & 0.39 & 22.55 \\
\hline Total carbohydrates & 0.23 & 0.25 & 0.35 & 0.36 & 0.59 & $\hat{\mathrm{Y}}=0.19+0.02 \mathrm{x} * *$ & 0.66 & 24.09 \\
\hline Non-fibrous carbohydrates & 1.16 & 1.26 & 1.64 & 1.25 & 2.39 & $\hat{\mathrm{Y}}=1.05+0.06 \mathrm{x}^{* *}$ & 0.47 & 23.88 \\
\hline \multicolumn{9}{|c|}{ Intake $\left(\mathrm{g} / \mathrm{kg} \mathrm{BW^{0,75 } )}\right.$} \\
\hline Nutrient & 50.48 & 50.62 & 63.97 & 48.00 & 90.79 & $\hat{\mathrm{Y}}=45.17+1.95 \mathrm{x}^{* *}$ & 0.37 & 23.07 \\
\hline Dry matter (\%) & 44.63 & 44.91 & 57.40 & 43.63 & 82.61 & $\hat{\mathrm{Y}}=39.70+1.87 \mathrm{x}^{* *}$ & 0.40 & 23.12 \\
\hline Organic matter (\%) & 3.20 & 3.73 & 4.79 & 4.43 & 7.52 & $\hat{\mathrm{Y}}=2.86+0.23 \mathrm{x}^{* *}$ & 0.65 & 20.78 \\
\hline Crude protein & 35.46 & 34.58 & 43.45 & 30.61 & 59.83 & $\hat{\mathrm{Y}}=31.83+1.12 \mathrm{x}^{*}$ & 0.26 & 24.86 \\
\hline Neutral detergent fiber & 22.25 & 20.95 & 26.50 & 19.18 & 35.13 & $\hat{\mathrm{Y}}=20.00+0.60 \mathrm{x}^{*}$ & 0.24 & 23.29 \\
\hline Acid detergent fiber & 1.17 & 1.26 & 1.89 & 1.23 & 2.66 & $\hat{\mathrm{Y}}=1.05+0.07 \mathrm{X} * *$ & 0.43 & 28.88 \\
\hline Ether extract & 40.26 & 39.91 & 50.71 & 37.97 & 72.42 & $\hat{\mathrm{Y}}=35.78+1.56 \mathrm{x}^{* *}$ & 0.37 & 23.37 \\
\hline Total carbohydrates & 4.79 & 5.33 & 7.26 & 7.36 & 12.59 & $\hat{\mathrm{Y}}=3.94+0.44 \mathrm{x} * *$ & 0.66 & 24.07 \\
\hline Non-fibrous carbohydrates & 25.50 & 26.46 & 34.26 & 25.60 & 50.84 & $\hat{\mathrm{Y}}=21.96+1.29 \mathrm{x} * *$ & 0.44 & 25.19 \\
\hline
\end{tabular}

$* 5 \%$ significance, $* * 1 \%$ significance. $\mathrm{R}^{2}=$ coefficient of determination; $\mathrm{CV}=$ coefficient of variation. 
the NDF intake increased by $1.12 \mathrm{~g}$ for each $1 \%$ of annato byproduct added. Although the NDF silage contents were reduced with the addition of annato byproduct, there was an increase in the NDF intakes that may have resulted from the increase in the DM consumption intake. Another explanation may also have been the increase in the CP content from 6.08 to $8.64 \%$, as previously commented, which favored microbial growth and in turn increased colonization in the fibrous fraction and favored the fermentation process.

Mizubuti et al. (2002) reported NDF intakes of 32.44, 37.46 and $41.35 \mathrm{~g} \mathrm{~kg}^{-1} \mathrm{BW}^{0.75}$, from the respective silages of sorghum, sunflower and corn and these results were close to the values estimated by regression equation in the present study, for the levels 0,5 and $8 \%$ annato byproduct. Reis et al. (2000) worked with elephant grass silage with the addition of passion fruit byproduct to the level of $50 \%$ and obtained NDF intake (42.97 $\left.\mathrm{g} \mathrm{kg}^{-1} \mathrm{BV}^{0.75}\right)$ similar to the level of $10 \%$ annato byproduct.

For every $1 \%$ of annato byproduct included in the elephant grass silage there was an increase of 0.03 percentage point in the $\mathrm{ADF}$ intake expressed in \%BW while for consumption in $\mathrm{g} \mathrm{kg}^{-1} \mathrm{BW}^{0.75}$, the ADF intake increased by $0.6 \mathrm{~g} \mathrm{ADF} \mathrm{kg}^{-1} \mathrm{BW}^{0.75}$ for every $1 \%$ of annato byproduct included.

Neiva et al. (2006) observed that the addition of dehydrated passion fruit byproduct to elephant grass silages did not influence the NDF and ADF intakes and presented means of 1.7 and $1.2 \%$ LW, respectively. However, it should be pointed out that the intakes expressed in \%LW were greater than those reported by Van Soest (1994) and NRC (2001), of 1.2\%. Similar data to those observed in the present study were presented by Neiva et al. (2005) when testing diets based on corn germ meal, where the NDF intakes expressed in \%LW reached $2 \%$.

Ether extract (EE) intake increased 0.003 percentage point for each $1 \%$ of annato byproduct added to the elephant grass silage when expressed in \%BW and $0.07 \mathrm{~g}$ EE when expressed in $\mathrm{g} \mathrm{kg}^{-1} \mathrm{BW}^{0.75}$. The higher EE intake with the addition of annato byproduct can be explained by the increase in the EE contents in the silages, which ranged from 2.13 at the level of $0 \%$ to 3.29 for the $16 \%$ level of annato byproduct.

Similar results were reported by Teles et al. (2010), in which the addition of mango byproducts at elephant grass ensilage resulted in a linear increase in EE intake by the animals. Similarly to the present study, the addition of mango by product raised the EE contents of the silage. It is important to point out that, even with the increases in $\mathrm{EE}$, the level that could damage the DM intake was not reached. Palmquist (1991) recommended that the ideal addition content was $5 \%$ in the total diet.

An increase of 0.7 percentage point $(\mathrm{P}<0.01)$ was observed for the total carbohydrate intake for each $1 \%$ of added annato byproduct. For the intake expressed in $\mathrm{g} \mathrm{kg}^{-1} \mathrm{BW}^{0.75}$, at every $1 \%$ annato byproduct included, the total carbohydrate intake increased by $1.56 \mathrm{~g} \mathrm{~kg}^{-1} \mathrm{BW}^{0.75}$. Similar data were obtained by Neiva et al. (2006) and Ferreira et al. (2009) who observed increases in the intakes of total carbohydrates with the addition of byproducts to sheep diets.

The addition of annato byproduct to the elephant grass silage showed an increasing linear effect $(\mathrm{P}<0.01)$ for the consumption of non-fibrous carbohydrates expressed in \%BW increased by 0.02 percentage point for each $1 \%$ of annato byproduct included in the elephant grass silage. For the consumptions expressed in $\mathrm{g} \mathrm{kg}^{-1} \mathrm{BW}^{0.75}$, the increase was $0.44 \mathrm{~g} \mathrm{~kg}^{-1} \mathrm{PV}^{0.75}$ for each $1 \%$ annato byproduct included. This fact was explained by the increase in CNF contents in the silages with the addition of annato byproduct, from $7.8 \%$ at the level of $0 \%$ annato byproduct to $12.6 \%$ for the $16 \%$ annato byproduct level, that is, a $61.54 \%$ increase in the CNF contents. The non-fibrous carbohydrates are easily fermented in the rumen, which permits a greater energy input to the animal rumen and consequently greater forage intake.

For each $1 \%$ of annato product added, increase was observed $(\mathrm{P}<0.01)$ of 0.6 percentage point in the TDN intakes in \%BW. For the TDN intake in $\mathrm{g} \mathrm{kg}^{-1} \mathrm{BW}^{0.75}$ there was an increase of $1,291.29 \mathrm{~g}^{\mathrm{NDT}} \mathrm{kg}^{-1} \mathrm{BW}^{0.75}$ for each $1 \%$ of annato byproduct included. The increase in the TDN intake was associated to increase in the energetic density of the silages with the addition of annato byproduct. Thus, it was clear that adding annato byproduct into elephant grass ensilage helped to overcome one of the limitations of using tropical grasses, namely energy efficiency.

There was no difference in the digestibility of the DM, OM, CP, EE, NDF, ADF and CNF ( $>>0.05)$ among the silages and their means were $55.95 \pm 5.18,58.19 \pm 4.81,45.34 \pm 7.97$, $34.96 \pm 14.77,52.79 \pm 5.82,45.79 \pm 6.54$ and $99.86 \pm 0.03 \%$, respectively (Table 3 ).

According to Van Soest (1994), high ADF contents in forage are associated to lower digestibilities. Although the ADF content of the silages decreased from 48.12 at the $0 \%$ annato byproduct level to $40.43 \%$ at the $16 \%$ annato byproduct level, there was no influence on the DM digestibility of the silage.

Ferreira et al. (2009) worked with elephant grass silage containing $0 ; 3.5 ; 7 ; 10.5$ and $14 \%$ pineapple juice extraction 
Table 3 -Nutrient digestibility and nitrogen balance in sheep fed elephant grass silage with annato byproduct

\begin{tabular}{|c|c|c|c|c|c|c|c|c|}
\hline & \multicolumn{5}{|c|}{ Level of annato by-product in the silage (\%) } & \multirow[t]{2}{*}{ Regression } & \multirow[t]{2}{*}{$\mathrm{R}^{2}$} & \multirow[t]{2}{*}{ CV (\%) } \\
\hline & 0 & 4 & 8 & 12 & 16 & & & \\
\hline Dry matter (\%) & 51.64 & 56.27 & 56.27 & 56.92 & 58.66 & $\hat{Y}=55.95 \pm 5.18$ & - & 9.26 \\
\hline Organic matter (\%) & 54.22 & 58.37 & 58.32 & 59.50 & 60.55 & $\hat{\mathrm{Y}}=58.19 \pm 4.81$ & - & 8.27 \\
\hline Crude protein (\%) & 36.67 & 44.26 & 42.79 & 48.40 & 44.55 & $\hat{Y}=45.34 \pm 7.97$ & - & 18.40 \\
\hline Ether extract (\%) & 20.06 & 35.29 & 46.48 & 33.22 & 39.73 & $\hat{Y}=34.96 \pm 14.77$ & - & 42.24 \\
\hline Neutral detergent fiber (\%) & 50.65 & 53.58 & 52.53 & 51.63 & 55.24 & $\hat{Y}=52.79 \pm 5.82$ & - & 11.02 \\
\hline Acid detergent fiber (\%) & 44.46 & 46.95 & 46.87 & 45.33 & 45.33 & $\hat{Y}=45.79 \pm 6.54$ & - & 14.24 \\
\hline Total carbohydrates (\%) & 56.62 & 60.27 & 60.18 & 61.61 & 62.96 & $\hat{Y}=57.52+0.35 x^{*}$ & 0.15 & 6.94 \\
\hline Non-fibrous carbohydrates (\%) & 100.00 & 100.00 & 100.00 & 100.00 & 99.29 & $\hat{\mathrm{Y}}=99.86 \pm 0.03$ & - & 1.34 \\
\hline Total digestible nutrients (\%) & 48.26 & 52.67 & 53.56 & 53.56 & 55.92 & $\hat{\mathrm{Y}}=49.55+0.40 \mathrm{x} * *$ & 0.18 & 8.58 \\
\hline Nitrogen balance (g/day) & 1.07 & 1.46 & 1.72 & 1.92 & 3.74 & $\hat{\mathrm{Y}}=0.82+0.14 \mathrm{x}^{* *}$ & 0.49 & 42.01 \\
\hline
\end{tabular}

*5 \% significance, **1\% significance. $\mathrm{R}^{2}$ - coefficient of determination; CV - coefficient of variation

byproduct and did not observe difference for DM digestibility with a mean of $53.31 \%$, a value lower than that obtained in the present study (55.95\%) which was similar to those obtained by Souza et al. (2003), who worked with hybrid sorghum silage, where they detected DM digestibility of 55.34\%. Thus, it can be inferred that the silage in the present study presented a nutrient use value close to that of conventional bulks, such as sorghum silage.

The digestibilities of the total carbohydrates and the TDN values inceased linearly as the annato byproduct was included. For each $1 \%$ of byproduct included, an increase of 0.35 and 0.4 percentage point was observed in the values of the digestibilities of the total carbohydrates and TDN, respectively. The increase in the TDN values may have been associated to the increases in the CNF and EE contents in the silage containing annato byproduct because differences were not observed in the apparent digestibilities of most of the nutrients. Thus it seems clear that increase in the TDN values was due to the increase in the more digestible nutrient contents in the silage and the increase in the digestibility of the total carbohydrates.

For the nitrogen balance, increases of $0.14 \mathrm{~g} \mathrm{day}^{-1}$ were observed in nitrogen retention $(\mathrm{P}<0.01)$ for every $1 \%$ annato byproduct included in the silage. The positive nitrogen balance indicated that the silages supplied the protein requirements for sheep maintenance and could guarantee some nutritional support for growth. The increase in nitrogen retention may have been a consequence of the better energy-protein balance of the food (NRC, 2007), and protein use was more efficient.

Neiva et al. (2006) observed that the nitrogen balance was negative for silages of elephant grass alone and positive for silages containing dehydrated passion fruit byproducts. The data obtained by Neiva et al (2006) were confirmed in the present study, in which the addition of annato byproduct raised the DM intake and positively influenced the nitrogen balance. Reis et al. (2000) also obtained positive nitrogen balance for elephant grass silage with the addition of passion fruit byproduct at the levels of 25, 50, 75 and 100\% and for silage with $93 \%$ elephant grass $+7 \%$ additive (3.5\% cotton meal and 3.5\% wheat meal). In the present study, the nitrogen balance was positive both for the increase in DM intake and for the increase in the CP contents of the silage (Tables 2 and 1). Thus it can be stated that the use of annato byproduct as absorbent additive improved the nutritive value of elephant grass silages.

\section{Conclusions}

The adition of annato byproduct at levels of $16 \%$ of the natural matter in the ensilage improves the nutritive value of the elephant grass silage. Thus, the economic feasibility of including this byproduct depends on its availability and purchase price.

\section{References}

AGRICULTURAL RESEARCH COUNCIL - ARC. The nutrient requirements of ruminant Livestock. London: Agricultural Research. Council, Commonwealth Agricultural Bureaux, 1980. 351p. BERNARDINO, F.S.; GARCIA, R.; ROCHA, F.C. et al. Produção e características do efluente e composição da silagem de capimelefante contendo diferentes níveis de casca de café. Revista Brasileira de Zootecnia, v.34, n.6, p.2185-2291, 2005.

COAN, R.M.; REIS, R.A.; GARCIA, G.R. et al. Dinâmica fermentativa e microbiológica de silagens dos capins tanzânia e marandu acrescidas de polpa cítrica peletizada. Revista Brasileira Zootecnia, v.36, n.5, p.1502-1511, 2007 (supl.).

CRAMPTON, E.W.; DONEFER, E.; LLOYD, L.E. A nutritive value index for forages. Journal of Animal Science, v.19, n.4, p.538-544, 1960.

EVANGELISTA, A.R.; LIMA, J.A.; BERNARDES, T.F. Avaliação de algumas características da silagem de gramínea estrela roxa (Cynodon nlemfuensis Vanderyst). Revista Brasileira de Zootecnia, v.29, n.4, p.941-946, 2000

FARIA, V.P.; TOSI, H.; GODOY, C.R.M. Polpa de laranja fresca e seca como aditivos para a ensilagem do capim-elefante Napier (Pennisetum purpureum Schum.). O Solo, v.64, n.1, p.41-47, 1972. 
FERREIRA, A.C.H.; NEIVA, J.N.M.; RODRIGUEZ, N.M. et al. Avaliação nutricional do subproduto da agroindústria de abacaxi como aditivo de silagem de capim-elefante. Revista Brasileira de Zootecnia, v.39, n.2 p.223-229, 2009.

GONÇALVES, J.S.; NEIVA, J.N.M.; CÂNDIDO, M.J.D. et al. Composição bromatológica e características fermentativas de silagens de capim-elefante (Pennisetum purpureum Schum.) cv. Roxo contendo níveis crescentes do subproduto da semente do urucum (Bixa orellana L.). Revista Ciência Agronômica, v.37, n.1, p.228-234, 2006.

HALL, M.B. Recent advanced in non-ndf carbohydrates for the nutrition of lactating cows. In: SIMPÓSIO INTERNACIONAL EM BOVINOS DE LEITE: Novos conceitos em nutrição, 2., 2001, Lavras. Anais... Lavras: Universidade Federal de Lavras, 2001. p.139-148.

CLEMENTINO, R.H. Utilização de subprodutos agroindustriais em dietas de ovinos de corte: consumo, digestibilidade, desempenho e caracteristicas de carcaça. 2008. 137f. Tese (Doutorado em Zootecnia) Universidade Federal do Ceará, Fortaleza.

LAVEZZO, W. Silagem de capim-elefante. Informe Agropecuário, v.11, n.132, p.50-57, 1985.

MIZUBUTI, I.Y.; RIBEIRO, E.L.A.; ROCHA, M.A. et al. Consumo e digestibilidade aparente das silagens de milho (Zea mays L.), sorgo (Sorghum bicolor (L.) Moench) e girassol (Helianthus annuus L.). Revista Brasileira de Zootecnia, v.31, n.1, p.267-272, 2002.

NEIVA, J.N.M.; NUNES, F.C.S.; CÂNDIDO, N.M.R. et al. Valor nutritivo de silagens de capim-elefante enriquecidas com subproduto do processamento do maracujá. Revista Brasileira de Zootecnia, v.35, n.4, p.1843-1849, 2006

NEIVA, J.N.M.; SOARES, N.A.; MORAES, S.A. et al. Farelo de glúten de milho em dietas para ovinos em confinamento. Revista Ciência Agronômica, v.36, n.1, p.111-117, 2005.

NATIONAL RESEARCH COUNCIL - NRC. Nutrient requirements of dairy cattle. 7.ed. Washington, D.C.: National Academy of Science, 2001. 381p.

NATIONAL RESEARCH COUNCIL - NRC. Nutrient requirements of sheep. 6.ed. Washington, D.C.: National Academy Press, 2007. 362p.

NUSSIO, L.G.; PAZIANI, S.F.; NUSSIO, C.M.B. Ensilagem de capins tropicais. In: REUNIÃO ANUAL DA SOCIEDADE BRASILEIRA DE ZOOTECNIA, 39., 2002, Recife. Anais... Recife: Sociedade Brasileira de Zootecnia, 2002. p.60-90.
PALMQUIST, D.L. Influence of source and amount of dietary fat on digestibility in lactating cows. Journal of Dairy Science, v.74, p.1354-1360, 1991.

REIS, J.; PAIVA, P.C.A.; TIESENHAUSEN, I.M.E.V.V. et al. Composição química, consumo voluntário e digestibilidade de silagens de resíduos do fruto de maracujá (Passiflora edulis Sims f. flavicarpa) e de capim-elefante (Pennisetum purpureum, Schum.) cv. Cameroon e suas combinações. Ciência Agrotecnologia, v.24, n.1, p.213-224, 2000.

RIBEIRO, J.L.; NUSSIO, L.G.; MOURÃO, G.B. Efeitos de absorventes de umidade e de aditivos químicos e microbianos sobre o valor nutritivo, o perfil fermentativo e as perdas em silagens de capim-marandu. Revista Brasileira de Zootecnia, v.38, n.2, p.230-239, 2009.

SILVA, D.J.; QUEIROZ, A.C. Análises de alimentos: métodos químicos e biológicos. 2.ed. Viçosa, MG: UFV, 2002. 165p.

SNIFFEN, C.J.; O'CONNOR, J.D.; VAN SOEST, P.J. A net carbohydrate and protein system for evaluating cattle diets: II. carbohydrate and protein availability. Journal of Animal Science, v.70, n.11, p.3562-3577, 1992.

SOUZA, I.; FARIA, J.O. A Cultura do urucum. [2000]. Disponível em: <http.//www.emater.mg.gov.br>. Acesso em: 03/01/2005.

SOUZA, V.G.; PEREIRA, O.G.; MORAES, S.A. et al. Valor nutritivo de silagens de sorgo. Revista Brasileira de Zootecnia, v.32, n.3, p.753-759, 2003.

STATISTICAL ANALYSES SYSTEM - SAS. User's guide. Cary: SAS Institute, 2001. 1028p.

TAVARES, V.B.; PINTO, J.C.; EVANGELISTA, A.R. et al. Efeitos da compactação, da inclusão de aditivo absorvente e do emurchecimento na composição bromatológica de silagens de capim-tanzânia. Revista Brasileira de Zootecnia, v.38, n.1, p.40-49, 2009

TELES, M.M.; NEIVA, J.N.M.; REGO, A.C. et al. Intake, nutrients digestibility and nitrogen balance of elephant grass silages with mango by-product addition. Revista Brasileira de Zootecnia, v.39, n.1, p.74-80, 2010.

VAN SOEST, P.J. Nutritional ecology of the ruminant. 2.ed. Ithaca: Cornell University Press, 1994. 476p.

VILELA, D.; CARNEIRO, J.C. Ensilagem do excedente de pasto: uma alternativa para o manejo. In: SIMPÓSIO SOBRE MANEJO ESTRATÉGICO DE PASTAGENS, 1., 2002, Viçosa, MG. Anais... Viçosa, MG: UFV, 2002. p.331-350.

WILKINSON, J.M. Silage made from tropical and temperate crops. 2. Techniques for improving the nutritive value of silage. World Animal Review, v.46, p.35-40, 1983. 